\title{
Migrants and Crime in Sweden in the Twenty-First Century
}

\author{
Göran Adamson ${ }^{1}$ \\ Published online: 13 January 2020 \\ (C) The Author(s) 2020
}

\begin{abstract}
In 2005, the Swedish Crime Prevention Agency published a report about the link between immigration and crime. Since then, no comprehensive study has been conducted even though Sweden has experienced a large influx of migrants in combination with a rising crime rate. This study conducted by Göran Adamson and Tino Sanandaji is the first purely descriptive scientific investigation on the matter in fifteen years. The investigation (from 2002 to 2017) covers seven distinct categories of crime, and distinguishes between seven regions of origin. Based on 33 per cent of the population (2017), 58 per cent of those suspect for total crime on reasonable grounds are migrants. Regarding murder, manslaughter and attempted murder, the figures are 73 per cent, while the proportion of robbery is 70 per cent. Non-registered migrants are linked to about 13 per cent of total crime. Given the fact that this group is small, crime propensity among non-registered migrants is significant.
\end{abstract}

Keywords Sweden · Crime · Migrants · Immigration · Sweden's Crime Prevention Agency · Refugees · Second-generation migrants $\cdot$ Non-registered migrants $\cdot$ Murder $\cdot$ Rape

\section{Are Racist Prejudices Fueled by Crime Statistics?}

"The situation for us Swedes is, then, infinitely more fortunate. Our population is homogeneous, not only in terms of our race but also regarding so many other issues." (Erlander, 1965, p. 60.) The words belong to Tage Erlander, Sweden's Social democratic Prime Minister between 1946 and 1969. We are a prosperous and fortunate country, he maintains, because we are unified. We think alike and act alike. By means of careful and persistent social measures, our population has slowly been trimmed and finetuned so as to achieve a historically unique sense of trust, social order and efficiency. In modern language, Erlander would claim that our country is fortunate because it is not characterized by multiculturalism and "diversity".

Since Erlander's time, a silent revolution has occurred at the heart of the reformist left. Now, diversity is said to give us prosperity, while defending the idea of a unified population is fraught with imminent political risks. Social democratic views of the 1960's are now considered far

Göran Adamson

goran.adamson@yahoo.se

1 Institutionen för Individ och Samhälle, West University, Gustava Melins gata 2, 46132 Trollhättan, Sweden right-wing - a psychological trauma as if straight out of an Ingmar Bergman movie.

As a result of the hegemony of multiculturalism and diversity in Sweden since the 1990s, we have accepted very large immigration, especially from the Middle East and Africa. During the refugee crisis of 2015 only, Sweden received 163,000 migrants. As a result of an expected immigration of relatives - often labeled "family unification", the figures might rise to over 2 million individuals.

Migration, we are told, is beneficial for Sweden. But if this is so, it would also show in crime statistics. According to the present investigation, the first more comprehensive study since the 2005 report by the Swedish Crime Prevention Agency, this is, however, not the case. In 2017, 58\% among those suspected for crime on reasonable grounds are migrants. Regarding murder and manslaughter, the corresponsing figures are $73 \%$. These figures are interesting out of purely scientific reasons. Due to migration, murder rate in Sweden has quadrupled.

As a universal role model for social and political prosperity, Sweden's recent crime trends has gained international attention. What can we do about it? What does it mean? The are no answers to these pressing questions. But Sweden might point towards an uncertain future. In a global world with increasing migration where the nation state is being eroded by neoliberals from the outside and multiculturalists from the inside, 
these Swedish trends may soon spread throughout the Western community.

In 2002, an editorial in Aftonbladet, Sweden's top selling tabloid, carried a warning: "Do not strengthen racist prejudices!" The newspaper had been informed that the Crime Prevention Agency, Sweden's official institution for the study of crime on an aggregate level, in its coming 2005 report would start presenting crime based on ethnic background. Aftonbladet was alarmed: "In case the Crime Prevention Agency distinguishes between "Swedes" and "immigrants", it will also imply that crime might be caused by ethnic background." This, Aftonbladet continued, "would instantly play into the hands of racists." "The right-wing extremists and their lies about a connection between ethnicity and crime, Aftonbladet concluded, "cannot pass unchallenged. But we need a serious debate. We certainly do not need crime statistics the mere presence of which only fuel racist prejudices." (Aftonbladet, June 27, 2002).

Aftonbladet appears troubled by the fact that, in case the Crime Prevention Agency will start distinguishing between Swedes and immigrants, "crime might be caused by ethnic background". The purpose of methodological distinctions, however, was always to look for plausible differences. When Aftonbladet claims that this "would instantly play into the hands of racists", the newspaper makes a remarkable concession, namely that racists will profit from scientific data.

True to the tone, Aftonbladet ends with a bold statement. Any connection in between ethnicity and crime is not only a "lie", but something verging on fascism. If we rely on data assembled by the Crime Prevention Agency, "a serious debate", Aftonbladet maintains, is no longer possible. Crime statistics "fuel racist prejudices." In case we wish to prevent racist exaggerations, then, the migration debate must be founded on the opposite of statistical data - i.e. outburts, stereotypes, exaggerations. This emotional anti-intellectualism as exemplified by Aftonbladet has defined Swedish migration discourse for decades.

The present report takes a different stance. Knowledge never lies - if it did, it wouldn't be knowledge. We need it to avoid extremist simplifications. The assumption that certain methodological distinctions must be kept out of sight of the public is dangerous and anti-democratic. Integration of marginalized groups is impossible without scientific data.

\section{Introduction and Purpose}

Today, criminal propensity among individuals with a foreign background counts as one of the most heated areas of debate. It is therefore important to acquire information regarding under-, and overrepresentation for different crimes. It is also important to investigate other group differences, such as men's overrepresentation regarding sexually related crimes, and the overrepresentation of crimes by individuals below the age of 30. Criminal predisposition among migrants is, however, especially important, because this particular group is an exogeneous factor constantly reshaping society, while the domestic male population is unchanging, or rather diminishing in relative terms as a result of immigration.

Criminal activity is weighing heavily on society, and on victims and relatives in particular. Proactively using scientific knowledge to counter criminal activity has, therefore, evident social benefits. As a result of the considerable societal cost of crime, even small discoveries and science-based insights is bound to have visible positive impact on social safety.

Over the last few decades, those who commit crimes in Sweden are increasingly clustered both geographically and socially. The risk of ending up as victim of crime is getting more and more unevenly distributed. (Nilsson and Estrada 2005) Inhabitants in so-called" vulnerable areas" are often migration with higher risk of being either criminal or victim of crime. Updating the data material on crime and migration leads to new and important data, and knowledge on crime and migration is seriously wanting, according to public institutions, politicians, and the majority population.

One of our main concerns here is to study the integration of second-generation migrants and how this integration has changed over time. Historically - from the 1940s to the end of the 1970 s - criminal migrants gradually tended to fuse with the majority population over time, both in terms of social status and regarding propensity for crime. An important task is to analyze if and if so to what extent these patterns of migration are still valid, and, in case this blending never occurs, to map those particularly vulnerable groups in order to initiate early preemptive action.

This entirely updated study questions the left-wing assumption that knowledge only fuels right-wing conspiracies. The truth is the opposite. In case we wish to fuel generalizations, stigmatizations based on anecdotes, rumors, political agitation etc., then we must try to prevent any attempt to acquire scientific knowledge. Knowledge undermines stereotypes and leads to more nuanced discussion. Numerous previous studies on crime and migration in Sweden are based on these assumptions.

There are many reasons why information on crime among migrants and their children is important. Detailed knowledge about groups prone for criminal behavior avoids random, costly, and inefficient measures. Knowledge tells us about longterm relations between migration and crime. Knowledge might inform us about why some cities and suburbs are more affected by crime than others. Continuously updated data material, finally, might tell us why different crimes fluctuate over time.

Over the recent past, the relation between criminal propensity and migration was subject of a number of Swedish studies - among them two reports by BRÅ (Sweden's Crime Prevention Agency). Its 1996 report analyzed the period between 1985 and 1989, while the report from 2005 studied data 
between 1997 and 2001. No further major investigation has, however, been conducted after 2001. This matter-of-fact has sparked a lively debate. Morgan Johansson, Sweden's Minister of Justice, has for instance kept saying that data on migrants and crime are unimportant "because we know that migrants are overrepresented in crime" (Johansson, 2018). Others, like the top selling tabloid Aftonbladet above, has insisted that this is not true, and that statistical data will only play into the hands of populists and racists.

Still, this unwillingness to update material remains controversial, and has been subject of various forms of critical remarks. While many seem to believe data on the relation between crime and migration is illegal, this is actually not the case. The 2005 study by the Crime Prevention Agency does not share the troubled opinions above:

But what about the risk that a new study on the theme might cause more harm than good? These kinds of concerns were raised when the plans to conduct the present study became public. New results may be subject to willful bias, critics maintained, taken out of context and being misrepresented, all of it leading to an increased polarization between groups. Clearly, these concerns must be taken seriously. Still, opinions about the relation between crime and migration based on scientific research, the Crime Prevention Agency maintains, is better than opinions based on subjective views and speculation. Unless we have facts about crime related to migrants and their off-spring, myths tend to spread and multiply. In case certain groups of migrants are in fact overrepresented, problems will not disappear just because we refuse to talk about them. Accurately describing the extent and development of the problems is likely to be the most effective way to deal with these matters, and to improve living conditions of all citizens in Sweden, irrespectively of ethnic background. (Brå 2005, p. 14-15)

Based on the above, the present study intends to investigate the development in registered crime among migrants and their children since the 2005 study by the Crime Prevention Agency. The underlying purpose is to find out whether an overrepresentation compared to native born Swedes prevails or not. The empirical material of the project is based on an extensive data survey provided by the Crime Prevention Agency, and in addition population data from Statistics Sweden (Statistiska centralbyrån - SCB).

\section{Background and Limitations}

In the introduction of the 1996 report by Crime Prevention Agency, immigration to Sweden was divided in three periods. The first period started at the end of WWII and consisted mainly of war refugees from Eastern and Central Europe, and the Baltic States. The second period, during the 1960s and 1970s, was dominated by work force immigration from Finland, Italy, Greece, Yugoslavia and Turkey. The third period, finally, started in the 1970s and continues to this day. Now, country of origin had shifted from Europe to countries outside of Europe, and workforce migration had been replaced by various categories of refugees.

When the Crime Prevention Agency in 2005 published a second report, the explicit purpose was to "update earlier research about registered crime among migrants" (Brå, 2005, p. 7). The primary background of this update was constituted by an increased immigration since the 1996 report. Ever since, the Agency continues:

(.) almost 300000 refugees have migrated to Sweden. The number of persons born in Sweden with one or two foreign-born parents has also increased. At the same time these individuals were hit by the recession of the 1990s. Hence, unemployment, social welfare, and housing segregation saw an increase among these groups (Brå 2005, p. 7). Sweden suffered during the 1990s' economic crisis, and there were huge cuts in the public sector, and unemployment rose to levels unseen since the depression of the 1930s. Compared to the immigrants from the 1980s, it was harder to obtain a job for those who had immigrated during the $1990 \mathrm{~s}$ (Socialstyrelsen, 2001, p. 90). We saw an increase in the percentage among foreign born defined as "poor", i.e. who earned less than half of Sweden's median income (Brå 2005, p. 14).

An important reason behind this report and the novel data it relies on is, hence, the fact that Sweden has seen a considerable influx of new refugees and migrants since 2001.

The report will also update figures on crime among second generation migrants - i.e. individuals born in their new host country with one or two foreign-born parents. This group has gained considerable attention in numerous international studies. It was also high-lighted in the 2005 report by the Crime Prevention Agency, stating that "the general picture presented by these studies is that this particular group, in comparison with both foreign-born and those born with two native parents, has a higher propensity for criminal activity.” (Brå 2005, p. 7).

Even if the Crime Prevention Agency has not revised its crime statistics for almost 15 years now, there are plenty of cases where authorities, researchers and media have presented information about migrants' share among those registered for crime. At this point, one TV-program, and three newspapers will be briefly discussed. 
In 2018, Uppdrag Granskning, a TV-program broadcasted on Swedish state television, surveyed every individual registered for rape or attempted rape between 2012 and 2017. 58\% were foreign-born. Among the remaining $42 \%$ born in Sweden, some had a migrant background as children to foreign-born, but their exact proportion was not presented. Among those registered for attempted, and completed sexual assault, where victim and criminal were strangers, a good $80 \%$ were foreign-born.

Another survey conducted in 2018 by the newspaper Aftonbladet studied 112 individuals registered for group rape (at least two offenders) since 2012. Among them, 73\% were foreign-born. In case those born in Sweden with two migrant parents were added, $88 \%$ were foreign-born.

In 2017, the newspaper Expressen did a survey of 192 individuals in Stockholm, who, according to police files, were either members of criminal gangs, or had links to criminal networks (as a result of court sentences or preliminary investigations). $82 \%$ were migrants, defined as being foreign-born or having two foreign-born parents. In case those with one foreign-born parent was added, the figure rose to $95 \%$.

Yet another set of data was assembled in 2017 by Dagens Nyheter. The material consisted of 100 criminals registered or suspected in investigations on gunfire on public places between 2013 and 2017. 90 of them (90\%) had one or two foreign-born parents. Among them, about every second had arrived in Sweden when they were young, while the rest were born in Sweden.

Among these particular types of registered criminal activity, a large proportion is foreign-born. Regarding other types of crime, the proportion of criminals with a Swedish background is much higher. Worth adding, the vast majority of migrants are, just like Swedes, law-abiding citizens. A survey conducted at Sahlgrenska Universitetssjukhuset in Gothenburg on registered crime between 1973 and 2004, showed that $96 \%$ of the population was entirely absent in the register for crime of violence. All crimes of violence are committed by a small proportion of individuals. Certain groups, namely men, juveniles and migrants are more prone for violence than others, but it is worth reiterating that the vast majority among then commit no crime whatsoever.

This is particularly important to bear in mind whenever crime statistics on group level is on the agenda. Otherwise populist simplifications will inevitably emerge, such as "migrants commit crimes". Generally, the relation between migrants and crime is a delicate issue and should be treated with caution to avoid generalizations and simplifications. There is an ever-present risk, and in Europe today even more so, that groups overrepresented in crime will be stigmatized and discriminated as groups. This leads to a common statistical error among laymen and politicians. The average height of boys in my class says nothing about my height. And the fact that I happen to be tall says little about group average, and even less about another boy in the class. Ethnic groups never commit crimes, individuals do.

The researcher should also address the limits of statistical material. Migrant crime is often, for instance, explained by poverty or other socioeconomic factors. Whether social deprivation suddenly occurs on arrival in the new host country, or whether it is rather the result of an earlier lifestyle cannot, however, be answered in the abstract without careful empirical analysis. (See further below.)

Crime statistics only shows individuals registered for crime. Yet, these figures might be exaggerated due to a tendency among crime witnesses - whether consciously or not to single out migrants. Excessive focus on migrants may also be contextualized by a comparison with three other groups with a significantly higher crime propensity - men, low earners, and those on social benefits.

It is important to point out that the overrepresentation among various groups always change and tends to decrease in the long run. As indicated by a related study in Norway over a similar period of time, overrepresentation gradually tends to become less pronounced. It is a question of great scientific value whether this applies to Sweden as well - for migrants as a whole or for certain groups among them.

Furthermore, statistics on migrants' crime participation is based on data provided by two categories within the judicial system: suspect or convicted. However, not all crimes are reported, and there are always a number of those who are innocent among those suspect or convicted. When data says a certain percentage of those convicted for, for instance, rape has a migrant background, the real figures may be higher or lower.

We touched upon the fact that one reason why crime among migrants may be exaggerated is because they might be subject to discrimination by the Swedish judicial system, or that crime victims may be prone to single out individuals with a migrant background. There are, on the other hand, tendencies whereby criminality among migrants might be underestimated, such as the fact that these crimes often take place in areas where witnesses choose to remain silent. Also, they often occur within clan structures out of sight of the legal system.

The respective impact of these various statistical uncertainties is obviously hard to estimate. The Crime Prevention Agency still maintains that statistics available on those suspected and convicted offer a good or very good approximation of real overrepresentation in criminal activity. Finally, three things should be brought in mind. First: the figures presented in this report relates to registered crime - not actual crime. Second: they say nothing about the question why certain groups are overrepresented in crime. This is a descriptive study. Third: migrants are not only overrepresented among criminals, but also among victims of crime. The last observation is worth a comment. It is often said, and particularly by 
those who are perceived as being "on the left", that we are only witnessing "infighting among criminals", and that "ordinary citizens are not endangered". They try to downplay the dangers and take the steam out of right-wing populists. But migrants with a propensity for crime are also individuals who should be protected as any citizen instead of being killed in gang shoot-outs. It is not clear why this approach would counter far right ideas. In fact, right-wingers make use of similar arguments, whereby migrants with a criminal behavior somehow do not count as our equals, and as long as "we" are not in danger, we can just close our eyes and quietly hope that the problem with simply solve itself. The idea smacks of upperclass detachment, whether it comes from a compassionate left or from a heartless right.

\section{Earlier Research}

An extensive, systematic literature on criminal activity among foreigners goes back more than a century. (See, for instance, Hourwich 1912; Taft 1933; Shaw and McKay 1942; Tonry 1997; Bucerius and Tonry 2014; Lehti 2015; Piopiunik och Ruhose 2017; Skardhamar 2017). More recently, research has focused those who are born in their new host country with one or two foreignborn parents. (Killias 1989; Martens 1997; Kardell and Carlsson 2009; Salmi et al. 2015). These reports all indicate that this group is more criminally active compared with both foreign-born, and those born in the country with two native parents.

In Sweden, a number of studies have been published where the definition of key concepts such as "registered crime" and "foreign-born" often vary. (See, for instance, Kardell 2011; Crime Prevention Agency, 2005; Beckley et al., 2014; Brå 2016, 2017). In the studies on the period between the late 1960 s and the 1980s, neither registered crime among foreign-born with Swedish citizenship, nor registered crime among Swedish-born to foreign-born parents could be statistically assembled due to lacking data. Instead, research almost exclusively compared individuals with a foreign citizenship with those with a Swedish citizenship.

Subsequently, and as a result of data becoming more easily available, a number of studies were conducted targeting foreign-born and children of migrants between the 1980s and the first decade of the new millennium. (Kardell 2011). These studies all showed that the proportion of migrants registered for crime was remarkably stable, indicating an "over risk" at roughly 2 throughout the period. (Over risk is similar to overrepresentation, save for the fact that the comparison is made only with native Swedes, instead of with the entire population.) No comprehensive Swedish population study exists, however, to tell us whether or not this pattern is still valid from 2010 onwards.
This article has two major ambitions:

1. Update crime propensity among foreign-born and their children from 2010 onwards.

2. Investigate whether or not migrants' seemingly fixed over risk at 2 for registered crime has changed.

Judging from international research, it is hard to tell whether migrants are more prone for criminal activities compared with the native population. According to scholars studying the US, the foreign-born population tend to be less criminal compared with the US-born population, while the situation in Europe and the Nordic counties often is the opposite.

Registered crime among migrants can be measured in many different ways. One method is to measure individuals suspect for crime beyond reasonable doubt. Another approach is to calculate those registered and convicted or prosecuted outside of court. These two methods of registered crime are likely to produce similar results.

In Sweden, numerous studies show that foreign-born, compared to the Swedish native population, have an overrepresentation in registered crime between 2 and 2,5. Over any given period of time, the proportion of foreign-born registered for crime as suspect or prosecuted is, hence, about twice as high as a corresponding Swedish native population. The over risk in crime in relation to the majority population varies between types of crime and region of origin. Certain regions of origin have about the same crime rate as the majority population. Generally, migrants' over risk tends to be higher regarding more serious crime, and lower with respect to acquisitive crime and traffic offence.

Over any given period of time, crimes reported to police authorities are only a fraction of crimes committed. Since a particular number of crimes always remains undiscovered, it is difficult to estimate factual crime rate in society. The factual number of undiscovered crimes are obviously impossible to estimate.

Another important question is to what extent over risk in registered crime reflects factual overrepresentation or whether it rather relates to problem of method, where an increased presence of migrants with a criminal record is due to discrimination in the judicial system, an increased likelihood to be singled out and reported, or greater police attendance in areas dominated by migrants. Based on a research survey, the Crime Prevention Agency presented various reports claiming that while migrants' crime may be slightly biased, most of the reported overrepresentation still reflects factual reality.

Why are migrants overrepresented in registered crime? Many reasons have been suggested, including socioeconomic factors such as unemployment, low income, and lacking education (Brå 2005; Hällsten et al. 2013) along with demographic factors. Migrants have a bias towards young men, and young men are generally more criminal. Difficulties to break 
up and resettle in a new country, and various problematic ways in which they are received in Sweden - sometimes called "integration practice" - have been raised as other plausible factors behind a criminal bias. (Brå 2005; Kardell 2011). The 1996 study by the Crime Prevention Agency gathered data on the number of crime suspects resident in Sweden between 1985 and 1989 based on country of birth, and then compared it with the total number of persons from each country resident in Sweden. The results showed an over risk for crime among foreign-born of 2.1 compared to individuals born in Sweden with two native parents. The statistical likelihood that any given migrant would commit a crime was, in other words, about twice as high compared to the likelihood for any given native Swede.

Skardhamar et al. (2014) compared crime participation among migrants in Norway and Finland. While migrants overall were overrepresented in crime in both countries, propensity for crime differed notably between country of origin. By and large, migrant groups overrepresented in crime in Norway exhibited the same tendency also in Finland.

Pfeiffer et al. (2018) examined the effect of refugees on crime in the German state of Niedersachsen by investigating crime participation over time. Altogether, refugees were overrepresented in crime, and crimes where refugees were registered increased rapidly over time. The report also brought to attention various investigations saying that the likelihood for refugees to be reported for crime is significantly higher than for German natives.

In 2017, the Norwegian Agency of Statistics investigated the overrepresentation studying crime among migrants and migrants' children between 1992 and 2015. Overall, both groups exhibited higher registered crime rate compared to native Norwegians. However, the over risk fluctuated: in 1992 it was 1.5 , going up to at most 1.8 in 2002, after which is actually decreased to 1.4 in 2015 . The report suggests various reasons behind it, such as a changing mix of migrants and natives, or a potentially better integration. The fact that the over risk in Norway has taken a downward turn after 2000 is highly interesting, and the question arises: Has a similar recent change taken place also in Sweden?

Studies on Sweden tend to show that migrants' children have a lower over risk compared to foreign-born: 1.5 between 1985 and 1989, and 1.6 between 1997 and 2001 respectively. (Brå 1996; Brå 2005). Sweden, hence, deviates from the international pattern, where migrants' children have a higher crime participation compared to first generation of migrants. (Brå 2005). According to a study on the period 1997-2001 by Kardell and Martens (2013), the total crime overrepresentation of migrants' children as a group is about the same as that of first-generation migrants. Migrants' children are actually less likely to be registered for crime compared to first generation migrants. It is, however, important to note that migrant children registered for crime are often registered for more than one crime.

This is an important insight, raising the question whether second generation migrants in Sweden, as in so many other countries, show a higher criminal propensity than first generation migrants, in particular regarding crimes of violence. In Statistisk sentralbyrås 2017 investigation about the situation in Norway, various categories of crime develop very differently between first and second generation migrants. The results in Denmark are similar. Here, second generation migrants with non-European parents are more overrepresented in registered crime (Danmarks Statistik 2016).

Another finding across Swedish studies is, worth repeating, the fact that migrants' over risk has remained surprisingly consistent over time - despite the fact that the group of migrants has shifted somewhat towards groups with a higher risk to be registered in crime. (von Hofer and Tham 1991; Kardell 2011). What is the cause of this stability? Does it still prevail?

High quality data allowing for standardized comparisons between groups is of a fairly recent date. While earlier studies focused foreign citizens, more recent investigations study migrants. Studies dealing with crimes related to migrants dates back to at least the 1960, but scholarly interest in systematic comparisons - and in particular regarding children to migrants - started only recently. More detailed investigations on registered crime among foreign-born and children to one or two migrants only stretches back to the end of the 1980s (Brå 1996; von Hofer and Tham 1991). Data on crimes among migrants' children are, however, only available from the turn of the millennium onwards. (Brå 2005; Kardell 2011; Kardell and Martens 2013).

As a result of the present study, we now have the opportunity to update the material with more than a decade. This time frame, worth underscoring, also witnessed significant changes in the size and composition of the population of migrants and their off-spring. A systematic long-term investigation, then, calls for an urgent update of the statistical material.

\section{Method and Data Material}

The main purpose of this report is to investigate the development over time of registered crime for migrants and migrants' children. Two research questions are particularly interesting.

Question No. 1: Migrants. Recently, we have seen a continuous, stable over risk of registered crime among migrants in Sweden of around 2. Are we witnessing a structural result likely to change very little in the long run? Or is it rather mere coincidence, accidentally indicating 2.0 a few times in a row? According to results from Norway, the over risk is fluctuating considerably and has taken a downward turn recently. What about Sweden? 
Question No. 2: Migrants' children. In contrast to many other countries, Sweden, as shown by earlier studies, displayed lower overrepresentation among migrants' children compared to migrants generally (von Hofer and Tham 1991; Brå 1996; Brå 2005). Is this pattern still valid, or is Sweden gradually complying to a general international trend?

Contrary to the general pattern of registered crime, migrants' children exhibit more crimes per suspect along with a higher likelihood for lifestyle criminality (Kardell 2011; Beckley et al. 2014). These are all interesting issues. The present study, however, is purely descriptive, and causes and mechanisms behind overrepresentation are left out.

This article is based on the 2005 study by the Crime Prevention Agency in order to allow for statistical comparisons. Similarly as the agency, we shall, hence, calculate data by comparing The Register over individuals suspected for crime with The Register of total population at Statistics Sweden.

In line with recommendations by Statistics Sweden (2002) about how to present public data material, the population will be separated into four groups as presented in Table 1.

According to earlier studies, migrants' average crime participation differs between categories of crime. (Brå 1996; Brå 2005; Kardell 2011). Sexual crime, for instance, has a higher overrepresentation than theft, and different categories of crime may change over time. In addition to total number of crimes, we shall also study seven distinct categories listed in Table 2. While the categorization is based on the 2005 report by the Crime Prevention Agency, categories are somewhat fewer. Less serious crimes are being summarized under" Other Crimes".

In numerous previous studies, data comprising everyone with a migrant background has been supplemented by data on migrants based on either country of origin, or region of origin. The findings suggest important differences in average crime rate. Average registered crime divided by region may also have evolved in different directions, as indicated by a recent Norwegian report (Statistisk sentralbyrå 2017).

This article will present data on everyone with a migrant background, and in addition separately present registered crime based on seven regions of origin - from where data on migrants' children are reliable and easy to access. These seven regions of origin are laid out in Table 3 . This article is based on geographical categorizations and the economic situation of country of origin and relates closely to the 2005 report by

Table 1 Separation of Sweden's population into four subgroups

(1) Individuals born in Sweden by two native-born parents

(2) Individuals born in Sweden by one native parent and one foreign-born parent

(3) Individuals born in Sweden by two foreign-born parents

(4) Individuals born abroad
Table 2 Seven different categories of crime

(1) Murder, manslaughter, deadly assault (incl. Attempt etc.)

(2) Assault incl. Maltreatment, aggravated assault, and particularly aggravated assault

(3) Rape and violent rape (incl. Attempt etc.)

(4) Other sexual crimes (excl. rape)

(5) Robbery, incl. Robbery with violence

(6) Theft, incl. Petty theft and grand theft

(7) All other crimes (excl. Crimes in above categories)

the Crime Prevention Agency. Only a small number of migrants come from the U.S., Canada, Australia and remaining Oceania. Therefore, they will be combined with Western Europe as they all share similar economic development.

Crime registered in Sweden can be linked to those who are nationally registered, but many crimes are committed by individuals from abroad on temporary visit to Sweden such as tourists, gangs travelling to Sweden to commit crimes, paperless migrants as well as newly arrived asylum seekers still awaiting permanent residency. Authorities have no clear picture about the number of individuals in Sweden at any given point in time who are not nationally registered. It is therefore hard to assess their level of overrepresentation in the material.

Still, it is possible to give a fairly accurate estimate on the level of crime conducted by suspects who are not nationally registered. According to the Crime Prevention Agency, this group was behind about 3\% of registered crime between 1985 and 1989, and about 7\% between 1997 and 2001 respectively. For our period of investigation, we shall similarly present the proportion of crimes by individuals not nationally registered. These findings will not, however, be included in any possible overrepresentation because this would require reliable data on total population of non-nationally registered within Sweden, and the authorities, as noted above, cannot provide this. This study will update the findings above by presenting data from 2002 to 2006, and from 2013 to 2017 respectively.

During this particular period in time, the number of crimes has increased - both by mere numbers and in relation to Sweden's population. As earlier noted, registered crime is always dependent on the level of reports and legal changes and

Table 3 Seven regions of origin for individuals with a foreign background

(1) Western countries (Western Europe and the U.S., Canada and Oceania)

(2) Eastern Europa (Incl. Russia, Azerbajdzjan, Georgia and Armenia)

(3) Latin America (Incl. Central America)

(4) Western Asia (Incl. Turkey, Iran and Afghanistan)

(5) Eastern Asia (Incl. India and Pakistan)

(6) Africa

(7) Unknown or stateless 
should not be seen as an objective measurement of criminal activity. The statistical material in this article is not based on registered crime, but on individuals suspected for crime on reasonable grounds. Practically, this means that this particular individual has been suspect of a crime by police, attorney or any other crime investigating authority, where substantial and objective circumstances seems to be at hand, strongly suggesting that the particular individual has in fact committed the crime in question.

In contrast to reported crime, the number of individuals suspected of crime on reasonable grounds have not seen an increase towards the end of the period but rather a decline. This might be caused by numerous factors, such as the proportion of resolved crimes and a certain backlog in the judicial process. The results of this study are likely to be affected by these considerations. If this is the case, some clarification might be provided by future statistical updates and by studies on individuals convicted for crime after a court process. On the basis of statistics provided by the Crime Prevention Agency, Fig. 1 shows the development of total number of crimes in relation to the population from 1985 to 2018.

\section{Results}

Individuals with a foreign background, earlier studies maintain, has been overrepresented in Swedish crime statistics, particularly those who are born in a foreign country. Albeit to a somewhat lesser degree, those born in Sweden with at least one foreign-born parent also exhibit a higher risk of being registered for crime. Statistics on migrants and crime has not, however, been revised since the publication of the

180

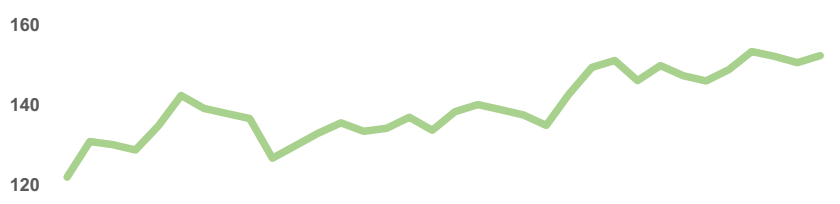

100

80

60

40

20

0

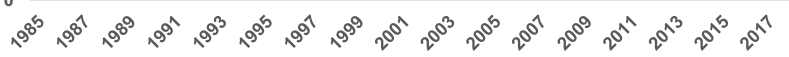

Fig. 1 Reported crime per 1000 inhabitants (Brå)
2005 report by the Crime Prevention Agency covering the period from 1997 to 2001.

This article is based on statistical material from the Crime Prevention Agency, using the same method as the agency in order to update the material to 2017. For the first time, the majority of those registered as crime suspects are foreignborn. The proportion of those with a foreign background increase from $18 \%$ between 1985 and 1989 to $33 \%$ between 2013 and 2017. During these two time intervals, the proportion of crime suspects with a foreign background went up from $31 \%$ to $58 \%$.

Concerning certain types of crime, migrants' over risk is even higher. Regarding murder and manslaughter, the proportion rose from $42 \%$ to $72 \%$. At the same time, however, migrants' over risk for crime only increased slightly. How is this possible? Because practically the entire increase in crime propensity among migrants was caused by the fact that their share of the population had increased. This is an important observation. The reason behind the rising trend, hence, has little to do with individual migrants becoming more prone to criminal activity. The over risk among the entire population of migrants increased from 1.8 between 1985 and 1989 to 2.0 between 1997 and 2001. No further changes have been registered between 2013 and 2017. Registered crime among those who are not nationally registered has, moreover, increased drastically.

If we compare first and second generation of migrants, the development has gone in the opposite direction. Since 2005 and the publication of the second report by the Crime Prevention Agency, the over risk for first generation of migrants has gone down, while it has increased for second generation of migrants born in Sweden. The downward turn regarding first generation of migrants also applies for individuals from countries outside of Europe, even if this material does not include some newly arrived refugees.

Sweden used to be somewhat of a statistical outlier, with second generation of migrants showing a clearly lower crime risk compared to first generation. At the time, Sweden resembled the development in Norway, according to Norwegian Statistics Office. As shown by the present article, these figures no longer apply. Instead, we are currently witnessing a rapid increase in registered crime among juveniles with a foreign background. The proportion of crime among individuals with a foreign background has increased not only in general terms but also regarding most crimes. One exception is constituted by rape and attempted rape, where the group's over risk has gone down considerably. Migrants' share of other sexual crimes has, simultaneously, increased. To what extent this is caused by changes in the definition of rape as a concept during our period remain, however, an open question.

Another striking change has to do with the increase of crime suspects among those who are not nationally registered. These individuals are all from abroad but absent in the group of migrants because they are not nationally registered. 
Table 4 Total number of crimes 2013-2017

\begin{tabular}{|c|c|c|c|c|}
\hline Total number of crimes & $\begin{array}{l}\text { Nationally Registered } 15-44 \text { years } \\
\text { of age on Dec. 31, } 2012\end{array}$ & $\begin{array}{l}\text { Suspected for crime on } \\
\text { reasonable grounds 2013-2017 }\end{array}$ & $\begin{array}{l}\text { Over risk } \\
\text { Suspicion of } \\
\text { crime }\end{array}$ & $\begin{array}{l}\text { Standardized for } \\
\text { gender and age }\end{array}$ \\
\hline \multirow{2}{*}{$\begin{array}{l}\text { Domestically born: two native } \\
\text { born parents }\end{array}$} & $2,036,027$ & 722,969 & 1,0 & 1,0 \\
\hline & 250,331 & 166,498 & 1,9 & 1,8 \\
\hline \multirow{2}{*}{$\begin{array}{l}\text { Domestically born: one native, } \\
\text { one foreign-born par. }\end{array}$} & 167,484 & 184,615 & 3,1 & 2,9 \\
\hline & 595,262 & 411,374 & 1,9 & 2,2 \\
\hline \multirow{2}{*}{$\begin{array}{l}\text { Domestically born: two } \\
\text { foreign-born parents }\end{array}$} & 87,255 & 29,103 & 0,9 & 1,1 \\
\hline & 146,497 & 100,853 & 1,9 & 2,2 \\
\hline Born abroad: & 36,160 & 27,748 & 2,2 & 2,3 \\
\hline Western countries & 164,324 & 151,357 & 2,6 & 2,7 \\
\hline Eastern Europe & 88,922 & 27,153 & 0,9 & 1,0 \\
\hline Latin America & 71,635 & 74,739 & 2,9 & 3,2 \\
\hline West Asia & $3,049,104$ & $1,485,456$ & 1,4 & 1,4 \\
\hline East Asia & & 218,526 & & \\
\hline Africa & & 1703982 & & \\
\hline \multicolumn{5}{|l|}{$\begin{array}{l}\text { Total excl. Not nationally } \\
\text { registered }\end{array}$} \\
\hline \multicolumn{5}{|l|}{ Not nationally registered } \\
\hline $\begin{array}{l}\text { Total incl. Not nationally } \\
\text { registered }\end{array}$ & & & & \\
\hline
\end{tabular}

Undocumented migrants, asylum seekers yet to enter the system, foreign gangs, and temporary visitors count among them. This group's share of total crime saw an increase from $3 \%$ between 1985 and 1989 to $13 \%$ between 2013 and 2017 . Information available for each and every definition within this group is unreliable. This means, for instance, that unregistered

Table 5 Over risk for various groups and types of crime in relation to native Swedes

\begin{tabular}{|c|c|c|c|}
\hline Total crime & Foreign background & Of which children to immigrants & Of which foreign-born \\
\hline 1985-1989 & 1.8 & 1.5 & 2.1 \\
\hline 1997-2001 & 2.0 & 1.6 & 2.5 \\
\hline $2002-2006$ & 2.1 & 1.7 & 2.4 \\
\hline 2013-2017 & 2.0 & 1.8 & 2.1 \\
\hline Murder & Foreign background & Of which children to immigrants & Of which foreign-born \\
\hline 1985-1989 & 2.7 & 1.5 & 3.5 \\
\hline 1997-2001 & 3.0 & 2.3 & 3.8 \\
\hline $2002-2006$ & 3.8 & 3.3 & 4.2 \\
\hline 2013-2017 & 4.1 & 4.3 & 3.9 \\
\hline Assault & Foreign background & Of which children to immigrants & Of which foreign-born \\
\hline \multicolumn{4}{|l|}{ 1985-1989 } \\
\hline $1997-2001$ & 2.3 & 1.7 & 2.9 \\
\hline $2002-2006$ & 2.4 & 1.9 & 2.8 \\
\hline 2013-2017 & 2.4 & 2.0 & 2.6 \\
\hline Robbery & Foreign background & Of which children to immigrants & Of which foreign-born \\
\hline 1985-1989 & 2.0 & 2.1 & 2.0 \\
\hline $1997-2001$ & 3.5 & 3.1 & 3.9 \\
\hline $2002-2006$ & 4.2 & 3.7 & 4.6 \\
\hline 2013-2017 & 3.1 & 3.9 & 2.6 \\
\hline Rape & Foreign background & Of which children to immigrants & Of which foreign-born \\
\hline 1985-1989 & 3.2 & 1.5 & 4.5 \\
\hline $1997-2001$ & 3.8 & 2.0 & 5.5 \\
\hline $2002-2006$ & 2.9 & 1.6 & 4.0 \\
\hline 2013-2017 & 2.2 & 1.6 & 2.6 \\
\hline
\end{tabular}




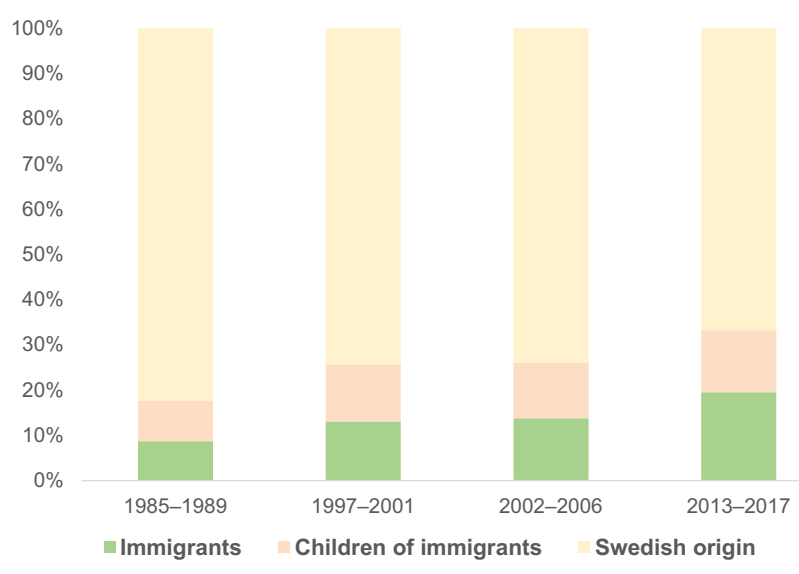

Fig. 2 Proportion of population

cannot be included in data about migrants' over risk for crime, because over risk measures likelihood to be registered for crime per person and non-registered are not identified. Then again, unregistered are included in the more general statistics about migrants' total number of crimes.

The number of those who are not nationally registered in Sweden is unknown. Migrants' over risk in crime would most likely rise in case undocumented migrants and asylum seekers were included in the definition. There is an added complexity here. As we saw above, the group of not nationally registered now constitutes a large proportion of registered crime. This, however, makes it harder to compare migrant groups, because we can't establish country of origin among those who are not nationally registered. The fact that undocumented migrants has shifted from being a marginal factor to constituting a significant proportion of all known crime suspects urgently calls for more research on this particular category.

Migrants' participation in crime is a cause for optimism as well as concern. Since the 2005 report by the Crime Prevention Agency, migrants' proportion of total crime has gone up. Regarding first generation of migrants, however, the over risk has subsided somewhat - both generally speaking and in relation to various crime categories. While this

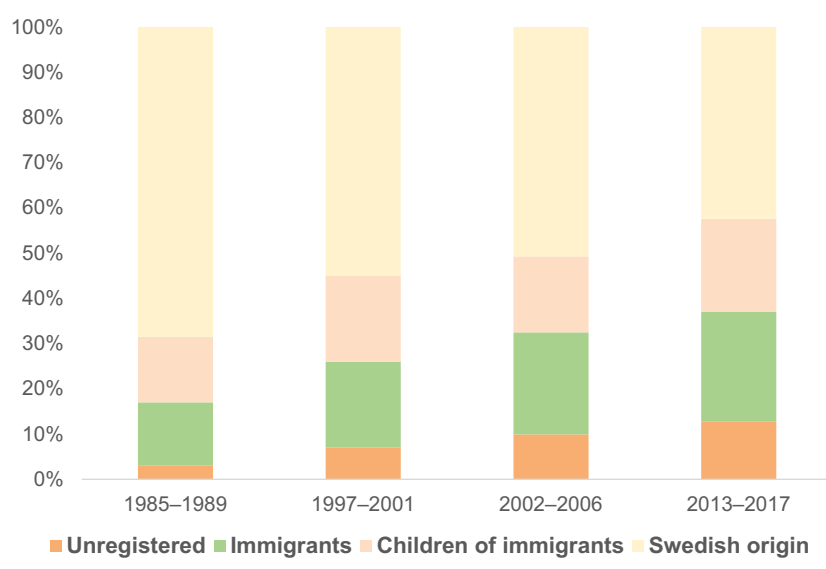

Fig. 3 Proportion of total crime

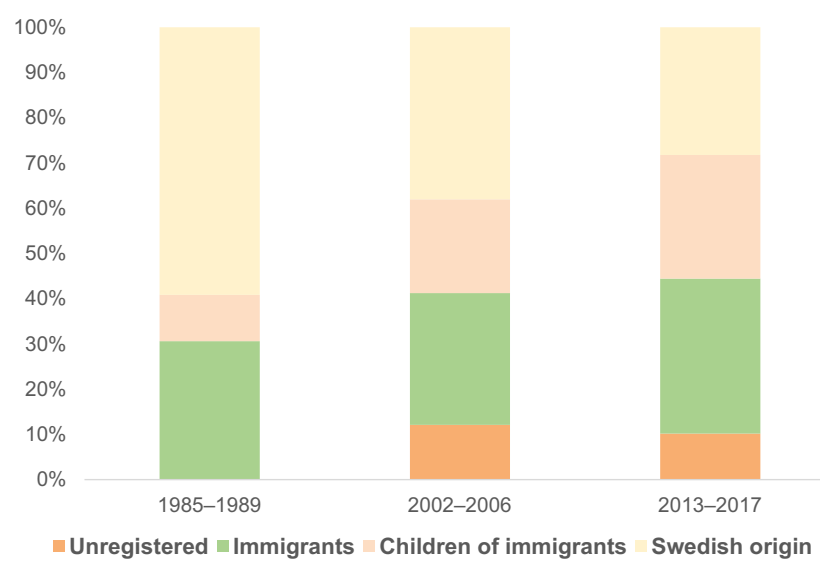

Fig. 4 Proportion of registered murder, manslaughter and attempted murder

decline is particularly strong concerning first generation of migrants from the West, it is also noticeable among first generation of migrants from non-Western countries. With regard to certain types of crime, it is now, on the basis of the 1996 and 2005 reports by the Crime Prevention Agency, possible to compare new data with earlier figures. This is, however, not possible concerning other types of crime as the reports fail to present this material is a way that allows for accurate comparisons or detailed analysis.

Assault, robbery and rape count among crimes where the over risk of first-generation migrants has declined. With regard to murder, however, an already high over risk among first generation migrants has increased further still. If we turn to rape, the over risk has declined for both first and second generation of migrants. On the other hand, the over risk has increased for assault and robbery by second generation of migrants. We are, moreover, witnessing a sharp upward turn in terms of second generation's over risk for murder.

The general trend remains basically the same, in case we standardize for age and gender. (See Table 4.) In the 1996 and 2005 report from the Crime Prevention Agency, adjustments were also made for so-called socio-economic factors, such as income, education, and occupation. Socio-economic factors

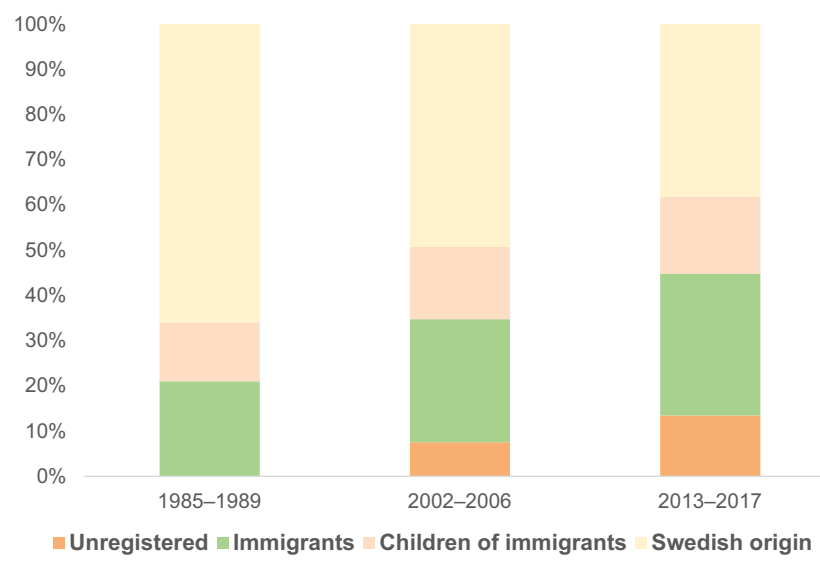

Fig. 5 Proportion of registered assault 


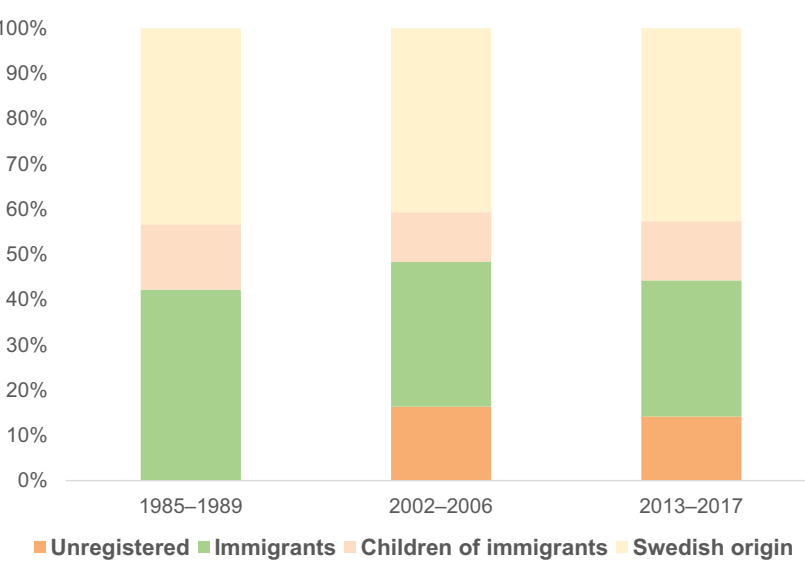

Fig. 6 Proportion of registered rape and attempted rape

should always be taken into consideration, and in the 1996 and 2005 reports, the over risk among migrants went down when they were applied. Still, socio-economic factors do not answer the question of causal relation and are therefore widely questioned. Whether poverty in a new host country leads to criminality, or a previous criminal behavior from the home county leads to poverty in the new host country is an open question and cannot be answered without rigorous analysis. Without taking sides in this discussion, it seems difficult to defend the idea that people immigrate into a country without a lifestyle and a rather firm set of personal beliefs. Therefore, this article has not taken socio-economic factors into consideration.

It should be noted that the data in Table 4 relates to total number of crimes, where one individual may commit more than one crime. Table 5, in contrast, presents the proportion of individuals registered for crime irrespective of number of crimes committed.

Figure 2 shows the proportion of the various groups under the four respective time periods. While the two earlier periods (1985-1989 and 1997-2001) correspond with the two reports by the Crime Prevention Agency, the two latter intervals

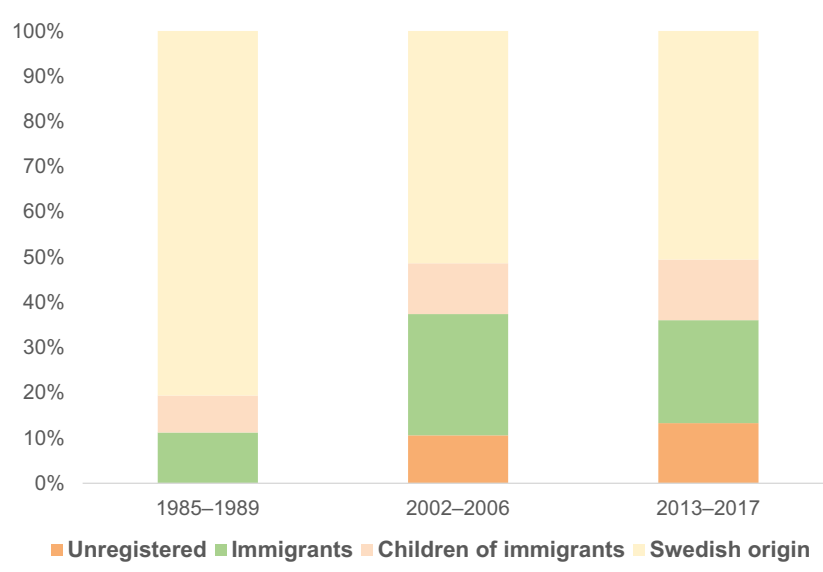

Fig. 7 Proportion of registered other sexual offences

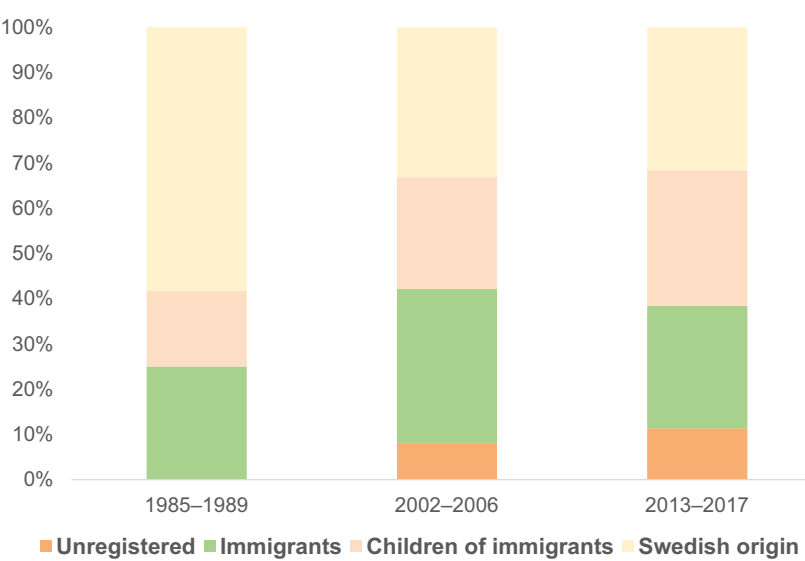

Fig. 8: Proportion of registered robbery.

(2002-2006 and 2013-2017) constitute the two periods of interest in the present article.

The various groups' proportion of being registered for suspicion of various crime is presented in Figs. 3, 4, 5, 6, 7, 8 .

Table 5 presents the over risk regarding various migrant groups compared to native Swedes. The over risk of the latest two periods of investigation has been compared with the two reports by the Crime Prevention Agency (1996 and 2005). (Age groups and other methods are not identical.) Data presented relates to proportion of individuals suspect of at least one crime at any point in time. The data does not, hence, account for the fact that certain individuals commit many crimes - a tendency, moreover, more common among migrants.

Total over risk among migrants has seen a moderate decline since the 2005 Crime Prevention Agency report. There are, however, significant differences in between groups. While the over risk has gone down among first generation of migrants, it has increased among children to migrants born in Sweden. In addition, the fairly widespread criminality among those who are not nationally registered is also absent in the material partly because there is no available statistics about the exact size of this particular population. Judging by estimates available on not nationally registered - undocumented migrants, asylum seekers and temporary visitors from abroad - the group is relatively small in size. This would probably mean that the crime over risk for the entire group of migrants has not, in fact, declined but increased compared with the earlier reports by the Crime Prevention Agency.

Figure 3 to Fig. 8 demonstrate that the proportion of crime committed by migrants has seen a steady increase, at the same time as the over risk remains fairly stable. There are three reasons for it.

1. These figures measure total number of registered crimes, taking into consideration the fact that some criminals commit more than one crime. In Table 5, in contrast, a person registered for crime is only counted once. 
Table 6 Estimated overrisk adjusted for unregistered migrants

\begin{tabular}{lll}
\hline Total crime & Foreign background, excluding unregistered & Foreign background, including unregistered \\
\hline $1985-1989$ & 1.8 & 2.1 \\
$1997-2001$ & 2.0 & 2.3 \\
$2002-2006$ & 2.1 & 2.6 \\
$2013-2017$ & 2.0 & 2.6 \\
\hline
\end{tabular}

2. Migrants share of the population is increasing. An increase in migrants' proportion of total registered crime does not require an increased over risk, as long as their share of the population is on the rise.

3. Those who are not nationally registered are included in Fig. 3 to Fig. 8. Criminal activity within this group has increased drastically.

It is hard to assess with any precision the number of unregistered present in Sweden at any given moment. Based on existing information, we may, however, make an estimate. See Table 6. Note that this table differ from earlier tables for two reasons. First, it includes an estimate of over risk where unregistered are present. Second, the definition of over risk is not as share of individuals registered for crime but based on total number of crimes for all migrants. The difference, then, relates to individuals who have committed more than one crime during the period of investigation. While Table 6 presents total crime for each and every group, Table 5 presents share of individuals in a group guilty of at least one crime. Since unregistered have a very high propensity for crime, their presence in the data will increase over risk for migrants compared to 1997-2011.

Between 2013 and 2017, for instance, 102,680 individuals were filed by the Swedish Migration Authority, most of whom belonged to the category unregistered. On the basis of the data by Statistics Sweden on booked nights on hotels and other facilities, the number of foreign visitors amounts to a year around population of about 40,000 individuals. Based on a state investigation on social care for undocumented individuals, their number was estimated at 10,000-35,000, while a government proposition on health care demand estimated this group to about 22,500 individuals. The Swedish Police has assessed the number of EU-migrants to around 4000-5000 individuals, while the number of cases of deportation has been estimated to 24,000. (Sveriges verkliga befolkningsmängd 2015/16).

These numbers are merely an approximation. Most likely, they include a certain double-count. Then again, foreign criminal gangs travelling through Sweden, visitors staying at friends, recurring cases of lacking data or incorrect information, and individuals not registered as crime suspects at the Crime Prevention Agency due to backlog, are all excluded. The number of un-registered are most likely larger within the age groups studied in this article. All in all, they would not count as more than a few per centage of total population, or about $10 \%$ of total migrant population.

Even if these approximations are vague, it is still possible to suggest an over risk for the total group of migrants including unregistered individuals. In the table below, it has been suggested that unregistered migrants make up about $10 \%$ of Sweden's total migrant population.

If unregistered individuals are left out in data since the 2005 report by the Crime Prevention Agency, the total over risk for migrants has decreased slightly. If they are included, however, it has increased. Various groups within the migrant population display notable differences. While the over risk has gone down among first generation migrants, it has increased among children to migrants born in Sweden.

Funding Information Open access funding provided by University West.

Open Access This article is licensed under a Creative Commons Attribution 4.0 International License, which permits use, sharing, adaptation, distribution and reproduction in any medium or format, as long as you give appropriate credit to the original author(s) and the source, provide a link to the Creative Commons licence, and indicate if changes were made. The images or other third party material in this article are included in the article's Creative Commons licence, unless indicated otherwise in a credit line to the material. If material is not included in the article's Creative Commons licence and your intended use is not permitted by statutory regulation or exceeds the permitted use, you will need to obtain permission directly from the copyright holder. To view a copy of this licence, visit http://creativecommons.org/licenses/by/4.0/.

\section{Further Reading}

Aftonbladet, S. 2002 June 27.

Beckley, Amber L., Johan Kardell and Jerzy Sarnecki. 2014. "Immigration and crime in Sweden". In the Routledge Handbook on Crime and International Migration, Sharon Pickering och Julie Ham (ed.), 41-54. London: Routledge.

Brottsförebyggande rådet (Brå). 1996. Invandrare och invandrares barns brottslighet: En statistisk analys. Author: Jan Ahlberg. Brå-rapport 1996:2. Stockholm: Fritzes.

Brottsförebyggande rådet (Brå). 2005. Brottslighet bland personer födda $i$ Sverige och $i$ utlandet. Författare: Peter Martens and Stina Holmberg. Brå-rapport 2005:17. Stockholm: Fritzes.

Brottsförebyggande rådet (Brå). 2016. Lagförda personer $i$ befolkningen 2000-2014: En studie av andelen lagförda bland kvinnor, män, $i$ olika åldersgrupper och för några utvalda brott. Author: Lisa 
Westfelt. Brå-kortanalys 3/2016. Stockholm: Brottsförebyggande rådet.

Brottsförebyggande rådet (Brå). 2017. Ny statistik över personer misstänkta för brott 2016". Nytt från Brå, March, 30, 2017. https://www.bra.se/nytt-fran-bra/arkiv/press/2017-03-30-nystatistik-over-personer-misstankta-for-brott-2016.html [accessed 2019-04-05].

Bucerius, Sandra M. och Michael Tonry (red.). 2014. The Oxford handbook of ethnicity, crime, and immigration. New York: Oxford University Press.

Statistik, D. 2016. Indvandrere i Danmark. Köpenhamn:Danmarks Statistik.

Erlander, T. 1965. Riksdagens protokoll vid lagtima riksmötet år 1965, Första kammaren, Volym 1.

von Hofer, Hanns och Henrik Tham. 1991. Foreign Citizens and Crime: The Swedish Case. Promemoria 1991:1. Stockholm: Statistiska centralbyrån.

Hourwich, Isaac Aaronovic. 1912. "Immigration and crime". The American Journal of Sociology 17, No. 4: 478-90.

Hällsten, Martin, Ryszard Szulkin and Jerzy Sarnecki. 2013. "Crime as a Price of inequality? The gap in registered crime between childhood immigrants, children of immigrants and children of native swedes". British Journal of Criminology 53, No. 3: 456-81.

Johansson, M. 2018. "Johansson: Inga fler kartläggningar om etniskt ursprung behövs“. SvT. 5 Feb. 2018. https://www.svt.se/nyheter/ inrikes/aktuellt-515 [accessed 2019-09-18].

Kardell, J. and Carlsson, K-M.. 2009. "Lagföringar av invandrare och invandrares barn i de nordiska länderna". Nordisk Tidsskrift for Kriminalvidenskab 96, No. 3: 237-61.

Kardell, J. and Martens, P.L. 2013. "Are children of immigrants born in Sweden more law-abiding than immigrants?: A reconsideration". Race and Justice 3, No. 3: 167-89.

Kardell, J. 2011. Utländsk bakgrund och registrerad brottslighet: Överrepresentationen i den svenska kriminalstatistiken. Doctoral dissertation, Dept. of Criminology, Stockholm University.

Killias, M. 1989. "Criminality among second-generation immigrants in Western Europe: A review of the evidence". Criminal Justice Review 14, No. 1: 13-42.

Lehti, M. 2015. "Crime Rates of Non-Resident Foreigners in Finland, 2009-2012." Journal of Scandinavian Studies in Criminology and Crime Prevention 16, No. 2: 194-202.

Nilsson, A. and Estrada, F. 2005. "Den ojämlika utsattheten: Utsatthet för brott bland fattiga och rika 1984-2001". Working paper 2005:8. Stockholm: Institutet för Framtidsstudier.
Martens, P. 1997. Immigrants, crime, and criminal justice in Sweden. Crime and Justice, 21, 183-255.

Pfeiffer, C., Baier, D. and Kliem, S. 2018. Zur Entwicklung der Gewalt in Deutschland Schwerpunkte: Jugendliche und Flüchtlinge als Täter und Opfer. Zürich: Departement Soziale Arbeit, Institut für Delinquenz und Kriminalprävention.

Piopiunik, M., \& Ruhose, J. 2017. Immigration, regional conditions, and crime: Evidence from an allocation policy in Germany. European Economic Review, 92, 258-282.

Salmi, V., Kivivuori J. and Aaltonen M. 2015. "Correlates of immigrant youth crime in Finland". European Journal of Criminology 12, No. 6: 681-99.

Shaw, C. R., \& McKay, H. D. 1942. Juvenile delinquency and urban areas: A study of rates of delinquents in relation to differential characteristics of local communities in American cities. Chicago: University of Chicago Press.

Skardhamar, T., Aaltonen M. and Lehti M. 2014. "Immigrant crime in Norway and Finland". Journal of Scandinavian Studies in Criminology and Crime Prevention 15, No. 2: 107-27.

Skardhamar, T. 2017. "Innvandrere og kriminalitet: en litteraturgjennomgang". Regjeringen, Departementenes sikkerhetsog serviceorganisasjon (DSS). https://www.regjeringen.no/ contentassets/2fa4635ae7b54a4aaab4d62cfa5bb2b5/innvandrereog-kriminalitet\%2D\%2D-en-litteraturgjennomgang.pdf [].

Socialstyrelsen. 2001. Social rapport 2001. Stockholm: Socialstyrelsen (Epidemiologiskt centrum).

Statistisk sentralbyrå. 2017. Kriminalitet blant innvandrere og norskfødte med innvandrerforeldre: En analyse av registerdata for perioden 1992-2015. Författare: Synøve N. Andersen, Bjart Holtsmark and Sigmund B. Mohn. Rapporter 2017/36. Oslo: Statistisk sentralbyrå.

Taft, D.R. 1933. "Does immigration increase crime?" Social Forces 12, No. 1: 69-77.

Tonry, M. 1997. Ethnicity, crime, and immigration. Crime and Justice, $21,1-29$.

Publisher's Note Springer Nature remains neutral with regard to jurisdictional claims in published maps and institutional affiliations.

Göran Adamson is an Associate Professor in Sociology, with a Ph.D. from the LSE. He is the author of 5 books, chiefly dealing with the reactionary tendencies of multiculturalism. His next book is entitled Masochist Nationalism - Multicultural Self-hatred and the Infatuation with the Exotic (Routledge, 2020). 